\title{
Daya Tarik Media Sosial dan Atribut Produk Terhadap Minat Kunjung Wisata di Ciwidey
}

\author{
Efi Fitriani ${ }^{1}$, Fitri Lestari ${ }^{2}$ \\ Program Studi Manajemen ${ }^{1,2}$, \\ STIE Ekuitas Bandung, Jl. PHH. Mustofa No. 31 Bandung ${ }^{1,2}$ \\ Email: efi_rani@yahoo.co.id ${ }^{1}$, fitri.lestari@ekuitas.ac.id ${ }^{2}$
}

\begin{abstract}
ABSTRAK
Penelitian ini bertujuan untuk mengetahui : 1) persepsi media sosial; 2) Persepsi atribut produk; 3) Persepsi minat kunjung; 4) besarnya pengaruh media sosial dan atribut produk terhadap minat kunjung wisata di Ciwidey Bandung. Metode yang digunakan dalam penelitian ini adalah deskriptif dan verifikatif melalui analisis regresi berganda. Adapun tekhnik sampling dalam penelitian ini menggunakan purposive sampling dengan jumlah responden sebanyak 100 orang yang memiliki akun media sosial instagram. Berdasarkan hasil analisis regresi berganda menunjukkan bahwa media sosial berpengaruh positif dan tidak signifikan terhadap minat kunjung wisata. Sedangkan untuk atribut produk berpengaruh positif dan signifikan terhadap minat kunjung wisata.
\end{abstract}

Kata kunci : media sosial, atribut produk, minat kunjung

\section{ABSTRACT}

This study aims to determine : 1) perceptions of social media; 2) perception of product attributes; 3) perceptios of visiting interest; 4) the magnitude of the influence of social media and product attributes on interest in visiting tours in Ciwidey Bandung. The method used in this research is descriptive and verification through multiple regression analysis. The sampling technique in this study used purposive sampling with a total of 100 respondents who have instagram social media accounts. Based on the results of multiple regression analysis, it show that social media has a positive and insignificant effect on interest in visiting tours. Meanwhile, product attributes have a positive and significant effect on interest in visiting tours.

Keywords : social media, product atribute

\section{PENDAHULUAN}

Media sosial adalah media online yang mendukung interaksi sosial. Media sosial telah menjadi pilar utama dalam penyampaian informasi seperti, dipergunakan untuk sosialisasi program dan kebijakan, memperkenalkan produk dan potensinya, memulihkan dan meningkatkan citra pariwisata serta media sosial dapat digunakan 
sebagai sarana pembelajaran masyarakat (Suryani, 2017). Khususnya pada Instagram, terkait dengan penggunaannya instagram sendiri merupakan salah satu media sosial yang sering digunakan dari berbagai kalangan saat ini. Di Indonesia sendiri penggunaan media sosial Instagram menempati urutan ke 3 sebagai pengguna aktif terbanyak dan terdapat pula 62 juta kali setiap bulannya dimanfaatkan sebagai media pemasaran (Social, 2019).

Berikut adalah negara yang menduduki peringkat 4 besar dengan jumlah pengguna instagram terbanyak di dunia yang jika diurutkan adalah: (1) Amerika Serikat -- total pengguna 110 juta atau 33.44 persen dari total populasi. (2) Brasil -- total pengguna 66 juta atau 31.38 persen dari total populasi. (3) India -- total pengguna 64 juta atau 4.68 persen dari total populasi (4) Indonesia -- total pengguna 56 juta atau 20.97 persen dari total populasi (teknologi.bisnis.com)

Dari hasil survei di atas dapat diketahui bahwa perkembangan social media di Indonesia memiliki peluang yang besar untuk dijadikan sebagai tempat pemasaran bagi para pebisnis yang ingin memasarkan produk atau jasanya. Social media merupakan bagian penting dari strategi penjualan, pelayanan, komunikasi, dan pemasaran yang lebih besar dan lebih lengkap serta merefleksikan dan menyesuaikan diri dengan pasar dan orang-orang yang mengartikannya. Instagram bukan hanya sebagai sarana komunikasi dan informasi saja, melainkan sudah mewabah kebeberapa sektor terutama pemasaran pariwisata.

Salah satu tempat di Indonesia, termasuk dalam provinsi Jawa Barat, yaitu tepatnya Kabupaten Bandung merupakan wilayah yang dianugerahi kecantikan dan keindahan alamnya yang asri. Kabupaten Bandung yang mempesona dengan pemandangan perbukitan dan kekayaan hutannya yang beragam, serta limpahan air jernih dari berbagai penjuru mata air, sehingga membuat wilayah Kabupaten Bandung sejuk, hijau dan asri.

Kawasan wisata Ciwidey merupakan salah satu kawasan wisata andalan yang diharapkan dapat mendatangkan wisatawan dalam jumlah yang besar. Mempunyai iklim yang sejuk dan secara geologis memiliki potensi sumber daya alam yang sesuai untuk kegiatan wisata terutama aktivitas wisata yang berkaitan dengan alam. Pada 
sektor pariwisata, Kawasan wisata Ciwidey mempunyai cukup banyak potensi untuk dikembangkan, sebagian besar potensi tersebut berupa wisata alam dan agro. (1) Kawasan Pariwisata Alam, meliputi: Gunung Patuha/Kawah Putih, Ranca Upas, Cimanggu, Walini, Situ Patengan, Kawah Cibuni, Curug Cisabuk (Kecamatan Rancabali), (2) Kawasan Pariwisata Budaya, meliputi: Gunung Padang (Kecamatan Ciwidey), Sentra Kerajinan (Kecamatan Pasirjambu), (3) Kawasan Pariwisata Agro, meliputi: Agrowisata Strawberry: Agrowisata Teh: Rancabali (Kecamatan Rancabali), Gambung (Kecamatan Pasirjambu); Agrowisata Sayuran: Kecamatan Pasirjambu, Kecamatan Rancabali, Kecamatan Ciwidey; Agrowisata Herbal: Kecamatan Rancabali, Kecamatan pasirjambu, Kecamatan Ciwidey. (4) Kawasan Pariwisata Terpadu dan Olahraga, meliputi: Stadion Si Jalak Harupat (Kecamatan Kutawaringin), Arena Golf Margahayu/BIG (Kecamatan Margahayu).

Dibandingkan dengan obyek wisata lain yang terdapat disekitarnya, Kawasan Wisata Ciwidey memiliki keunggulan dalam kemampuannya mendatangkan wisatawan. Kesejukan dan keindahan alam, suasana di kawasan ini menyebabkan wisatawan terutama yang datang dari Jakarta banyak memperoleh kenikmatan dan kenyamanan saat melakukan aktivitas wisata. Berdasarkan rata-rata pengeluaran wisatawan domestik yang didominasi oleh pengeluaran akomodasi/penginapan, makan dan minum serta belanja (shopping). Pengeluaran untuk makan dan minum meliputi aktivitas makan dan minum di restoran, café, warung makanan sebesar Rp 62.829,$(17.40 \%)$ dan tempat seperti toko, swalayan, minimarket ataupun supermarket sebesar Rp 298.257,- (82,60\%).

Data ini memperlihatkan bahwa wisata kuliner merupakan daya tarik utama wisatawan domestik mengunjungi Kabupaten Bandung. Kebutuhan makan dan minum sangat tinggi sehingga merupakan salah satu atribut pendukung pariwisata yang cukup penting. Fasilitas restoran dan rumah makan bersama dengan akomodasi merupakan fasilitas/amenitis yang sangat penting bagi Kawasan Wisata Ciwidey Kabupaten Bandung, karena sebagian besar pendapatan daerah berasal dari pajak kedua industri ini. Walaupun demikian tidak ada standar pelayanan hotel dan restoran, jumlah kamar 
sangat sedikit jika dibandingkan dengan jumlah wisatawan yang datang, jenis penginapan lote-hotel kecil, penginapan, bungalow dan Vila.

Berbagai pilihan untuk menentukan pada destinasi yang mana akan menjadi keputusan untuk berlibur bagi wisatawan, maka perlu bagi pengelola kawasan (obyek wisata) untuk mengembangkan produk wisata sesuai dengan keinginan wisatawan supaya bisa bersaing dengan destinasi yang lain, dengan cara mempermudah kegiatan wisatawan dalam melakukan wisata sehingga dapat mempengaruhi wisatawan dalam mengambil keputusan.

Tabel 1. Jumlah Wisatawan Yang Berkunjung ke Kab. Bandung

\begin{tabular}{|c|c|}
\hline Tahun & Jumlah wisatawan \\
\hline 2016 & 6.450 .468 \\
\hline 2017 & 3.964 .181 \\
\hline 2018 & 2.600 .000 \\
\hline
\end{tabular}

Sumber : BPS 2019

Berdasarkan data tersebut menunjukkan bahwa kunjungan wisata di kabupaten bandung mengalami penurunan dalam tiga tahun terakhir. Pada tahun 2016 jumlah kunjungan wisatawan berjumlah 6.45 .468 orang, kemudian menurun menjadi 3.964.181 pada tahun 2017 dan menurun lagi menjadi 2.600.000 pada tahun 2018 .

Identifikasi masalah penelitian adalah menentukan pengaruh sosial media dan atribut produk terhadap minat kunjung wisata di Ciwidey dan mentukan strategi apa yang digunakan untuk meningkatkan minat kunjung wisata di Ciwidey.

Electronic of mouth bisa mendorong pembelian yang dilakukan konsumen, bisa mempengaruhi komunitas, dan efisiensi karena tidak memerlukan budget yang besar (low cost), bisa menciptakan image atau dampak positif bagi produk, dan bisa menyentuh emosi konsumen. (Sumardy, Silviana, \& Melone, 2011)

Atribut produk sebagai unsur-unsur produk yang dipandang penting oleh konsumen dan dijadikan dasar pengambilan keputusan pembelian. (Tjiptono, 2008) Hal ini sesuai dengan penelitian (Akpoyomare, Ben, Adeosun, \& Ganiyu, 201) yang menjelaskan 
bahwa atribut produk memiliki peranan yang sangat penting dalam perspektif konsumen dan pemasar.

(Muljadi, 2010) menyatakan bahwa terdapat tiga aspek penting dari produk pariwisata agar calon wisatawan melakukan kunjungan yaitu daya tarik wisata (atraksi wisata), kemudahan mencapai daerah tujuan wisata (aksesbilitas), dan fasilitas yang tersedia di tujuan wisata (amenitas). Sedangkan (Hasan, 2015) menyatakan bahwa dari sudut pandang (calon) wisatawan mempertimbangkan segala bentuk kunjungan, produk harus dirancang dalam sebuah paket yang terdiri dari komponen berwujud atau tidak berwujud dan aktivitas di destinasi harus dapat dirasakan oleh wisatawan sebagai pengalaman yang bersesuaian dengan harga pasar. Paling tidak ada lima komponen yang harus dipertimbangkan saat membuat tawaran produk wisata, yaitu atraksi dan lingkungan, fasilitas dan layanan, aksesbilitas, citra destinasi, dan harga.

Media sosial berpengaruh signifikan terhadap variabel minat berkunjung FOLLOWERS (Survei Pada Followers Akun Instagram (a)batuflowergarden.Cobanrais) (Sunarti, 2019). Sejalan dengan itu (Amartin, 2018), Akun Instagram berpengaruh secara positif terhadap minat kunjung wisata di Banten. (Nifita \& Arishonda, 2017) media sosial (Facebook, YouTube, dan Instagram) secara simultan berpengaruh signifikan terhadap minat berkunjung wisatawan di taman Geopark kabupaten Merangin.

Atribut produk wisata dan eWOM secara simultan berpengaruh terhadap keputusan berkunjung pada objek wisata Umbul Sidomukti Kabupaten Semarang (Hapsari, Lubis, \& Widiartanto, 2014). Hal ini sejalan dengan penilaian kegiatan wisata, tidak hanya telah dilakukan pada pariwisata yang berbasis alam dan budaya. (Sanchez-Cañizares \& Castillo-Canalejo, 2015) telah melakukan studi yang mengukur sikap wisatawan akan kegiatan wisata kuliner di Spanyol dan Slovenia dengan menggunakan attributed related to gastronomy, yaitu: service and hospitality, quality of dishes, atmosphere establishments, facilities, prices, dan innovative. 


\section{METODOLOGI PENELITIAN}

Analisis data yang digunakan adalah analisis deskriptif dan analisis regresi. Analisis deskriptif untuk menjelaskan persepsi konsumen terhadap sosial media, atribut produk dan minat beli. Dan analisis regresi untuk mencari pengaruh sosial media dan atribut produk terhadap minat kunjung kawasan wisata Ciwidey.

Populasi penelitian ini adalah wisatawan yang mengunjungi kawasan wisata Ciwedey dan teknik yang digunakan dalam pengambilan sample penelitian ini menggunakan metode non probability sampling, yaitu metode pengambilan sampel dengan tidak memberikan kesempatan yang sama bagi setiap unsur atau anggota populasi untuk dipilih menjadi sampel dan menggunakan teknik purposive sampling. Melalui teknik ini peneliti memiliki keuntungan dalam menentukan sampel secara cepat, mudah dan relevan dengan jumlah 100 responden.

Tabel 2. Operasionalisasi Variabel

\begin{tabular}{|c|c|c|c|}
\hline No & Variabel Penelitian & Dimensi & Indikator \\
\hline 1 & $\begin{array}{l}\text { Media } \\
\text { Instagram }\end{array}$ & $\begin{array}{l}\text { Social Presence } \\
\text { Social Presence dapat } \\
\text { diartikan dengan kontak } \\
\text { yang terjadi ketika terjadi } \\
\text { proses komunikasi } \\
\text { penilaian responden atas } \\
\text { dimensi social presence } \\
\text { yaitu interaksi media sosial. }\end{array}$ & $\begin{array}{l}\text { 1. Kemunculan } \\
\text { foto/video di } \\
\text { timeline setiap hari } \\
\text { 2. Kemunculan } \\
\text { foto/video } \\
\text { menyampaikan } \\
\text { informasi kawasan } \\
\text { wisata ciwidey setiap } \\
\text { hari } \\
\text { 3. Kemunculan foto } \\
\text { atau video untuk } \\
\text { menyapa followers } \\
\text { setiap hari } \\
\text { 4. Ketertarikan pesan } \\
\text { yang disampaikan } \\
\text { 5. Kejelasan dalam } \\
\text { penyampaian pesan }\end{array}$ \\
\hline & & $\begin{array}{l}\text { Media Richnes } \\
\text { Media Richnes dapat } \\
\text { diartikan dengan } \\
\text { mengurangi ketidakjelasan } \\
\text { dan ketidaknyamanan } \\
\text { informasi melalui proses } \\
\text { komunikasi. }\end{array}$ & $\begin{array}{l}\text { 1. Kualitas foto dan } \\
\text { video jelas } \\
\text { 2. Postingan foto } \\
\text { menarik } \\
\text { 3. Desain foto atau } \\
\text { video menarik } \\
\text { 4. Caption menarik }\end{array}$ \\
\hline
\end{tabular}




\begin{tabular}{|c|c|c|c|}
\hline No & Variabel Penelitian & Dimensi & Indikator \\
\hline & & & $\begin{array}{l}\text { 5. Hashtag menarik dan } \\
\text { memudahkan } \\
\text { pencarian } \\
\text { 6. Kelengkapan } \\
\text { informasi dan kontak } \\
\text { tempat wisata } \\
\text { 7. Kejelasan } \\
\text { mencantumkan } \\
\text { informasi produk } \\
\text { wisata }\end{array}$ \\
\hline & & $\begin{array}{l}\text { Self Disclosure } \\
\text { Self disclosure diartikan } \\
\text { sebagai mengembangkan } \\
\text { hubungan dekat dengan } \\
\text { melalui pengungkapan diri } \\
\text { seperti perasaan, suka, tidak } \\
\text { suka, dan pemikiran. } \\
\text { Melalui media sosial } \\
\text { konsumen } \\
\text { mengutarakan dapat } \\
\text { pengungkapannya. }\end{array}$ & $\begin{array}{l}\text { 1. Cepat tanggap } \\
\text { memberikan respon } \\
\text { terhadap foto atau } \\
\text { video yang di tag } \\
\text { 2. Cepat tanggap } \\
\text { membalas komen } \\
\text { dikirimkan dalam } \\
\text { caption } \\
\text { 3. Memberikan like } \\
\text { pada postingan } \\
\text { 4. Memberikan } \\
\text { comment } \\
\text { menanyakan } \\
\text { informasi produk } \\
\text { 5. Mengirimkan } \\
\text { comment untuk } \\
\text { mengomentari } \\
\text { postingan } \\
\text { Memberikan hashtag } \\
\text { untuk mengajak dan } \\
\text { merekomendasikan } \\
\text { kepada teman yang } \\
\text { lain. }\end{array}$ \\
\hline 2 & $\begin{array}{lr}\text { Atribut } & \text { produk } \\
\text { adalah } & \\
\text { pengembangan suatu } \\
\text { produk atau jasa } \\
\text { melibatkan } & \text { manfaat } \\
\text { yang } & \text { akan } \\
\text { ditawarkan } & \text { produk } \\
\text { atau jasa } & \text { tersebut } \\
\text { (Kottler } & \text { \& } \\
\text { Armstrong, 2012) }\end{array}$ & $\begin{array}{l}\text { Attraction (daya tarik); } \\
\text { daerah tujuan wisata } \\
\text { (selanjutnya disebut DTW) } \\
\text { hendaknya memiliki daya } \\
\text { tarik, baik daya tarik berupa } \\
\text { alam maupun masyarakat } \\
\text { dan budayanya untuk } \\
\text { menarik wisatawan }\end{array}$ & $\begin{array}{l}\text { 1. Ketertarikan alam } \\
\text { 2. Ketertarikan budaya } \\
\text { 3. Ketertarikan acara } \\
\text { event } \\
\text { 4. Ketertarikan kegiatan } \\
\text { rekreasi } \\
\text { 5. Ketertarikan pusat } \\
\text { hiburan }\end{array}$ \\
\hline
\end{tabular}




\begin{tabular}{|c|c|c|c|}
\hline No & Variabel Penelitian & Dimensi & Indikator \\
\hline & & $\begin{array}{l}\text { Accesable (dapat dicapai); } \\
\text { hal ini bertujuan agar } \\
\text { wisatawan domestik dan } \\
\text { mancanegara dapat dengan } \\
\text { mudah mencapai tempat } \\
\text { wisata }\end{array}$ & $\begin{array}{l}\text { 1. Jarak dari pusat ibu } \\
\text { kota } \\
\text { 2. Kondisi jalan umum } \\
\text { 3. Kondisi jalan objek } \\
\text { wisata } \\
\text { 4. Ketersediaan } \\
\text { transportasi }\end{array}$ \\
\hline & & $\begin{array}{l}\text { Amenities (fasilitas); } \\
\text { fasilitas merupakan salah } \\
\text { satu syarat daerah tujuan } \\
\text { wisata sehingga wisatawan } \\
\text { dapat betah tinggal lebih } \\
\text { lama di daerah tersebut. }\end{array}$ & $\begin{array}{l}\text { 1. Ketersediaan tempat } \\
\text { penginapan } \\
\text { 2. Ketersediaan rumah } \\
\text { makan } \\
\text { 3. Ketersediaan fasilitas } \\
\text { pendukung } \\
\text { pariwisata seperti } \\
\text { ATM centre. } \\
\text { 4. Kondisi infrastruktur }\end{array}$ \\
\hline & & $\begin{array}{l}\text { Ancillary (adanya lembaga } \\
\text { pariwisata); keberadaan } \\
\text { lembaga pariwisata dapat } \\
\text { membuat wisatawan merasa } \\
\text { lebih aman (protection of } \\
\text { tourism) dan terlindungi } \\
\text { sehingga akan semakin } \\
\text { sering dikunjungi dan dicari } \\
\text { wisatawan. }\end{array}$ & $\begin{array}{l}\text { 1. Kualitas pelayanan } \\
\text { pegawai pemerintah } \\
\text { atau pengelola. } \\
\text { 2. Penerimaan } \\
\text { masyarakat setempat }\end{array}$ \\
\hline \multirow[t]{2}{*}{3} & $\begin{array}{l}\text { Minat beli minat beli } \\
\text { adalah sesuatu yang } \\
\text { timbul setelah } \\
\text { menerima } \\
\text { rangsangan } \\
\text { produk dari } \\
\text { dilihatnya, yang } \\
\text { muncul keinginan } \\
\text { untuk membeli dan } \\
\text { memilikinya. (Kotler } \\
\text { \& Amstrong, 2012) }\end{array}$ & $\begin{array}{l}\text { Minat transaksional: } \\
\text { kecenderungan seseorang } \\
\text { untuk membeli produk. } \\
\text { Maksudnya, konsumen } \\
\text { telah memiliki minat untuk } \\
\text { melakukan pembelian suatu } \\
\text { produk tertentu yang ia } \\
\text { inginkan. }\end{array}$ & 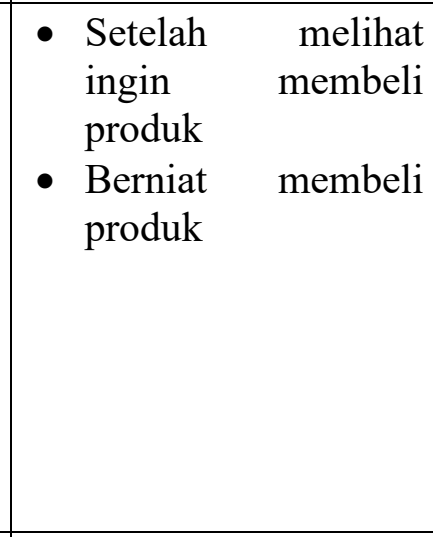 \\
\hline & & $\begin{array}{l}\text { Minat referensial : } \\
\text { kecenderungan seseorang } \\
\text { untuk mereferensikan } \\
\text { produk kepada orang lain. } \\
\text { Maksudnya, seorang } \\
\text { konsumen yang telah }\end{array}$ & \begin{tabular}{ll} 
- & \multicolumn{2}{l}{ Merekomendasikan } \\
produk kepada \\
orang lain \\
- Mengajak orang \\
lain untuk membeli \\
produk tersebut
\end{tabular} \\
\hline
\end{tabular}




\begin{tabular}{|c|c|c|c|}
\hline No & Variabel Penelitian & Dimensi & Indikator \\
\hline & & $\begin{array}{l}\text { memiliki minat untuk } \\
\text { membeli akan menyarankan } \\
\text { orang terdekatnya untuk } \\
\text { juga melakukan pembelian } \\
\text { produk yang sama. }\end{array}$ & \\
\hline & & $\begin{array}{l}\text { Minat preferensial : } \\
\text { minat } \\
\text { menggambarkan perilaku } \\
\text { seseorang yang memiliki } \\
\text { preferensi utama pada } \\
\text { produk tersebut. Preferensi } \\
\text { ini hanya bisa diganti } \\
\text { apabila terjadi sesuatu } \\
\text { dengan } \\
\text { preferensinya. }\end{array}$ & $\begin{array}{l}\text { - Menentukan produk } \\
\text { tersebut sebagai } \\
\text { pilihan utamanya } \\
\text { - Akan menggantikan } \\
\text { produk tersebut } \\
\text { dengan yang lain } \\
\text { kalau produk itu } \\
\text { tidak lagi } \\
\text { disenanginya }\end{array}$ \\
\hline & & $\begin{array}{l}\text { Minat eksploratif: } \\
\text { menggambarkan perilaku } \\
\text { seseorang yang selalu } \\
\text { mencari informasi } \\
\text { mengenai produk yang } \\
\text { diminatinya dan mencari } \\
\text { informasi untuk mendukung } \\
\text { sifat positif dari produk } \\
\text { tersebut. }\end{array}$ & $\begin{array}{l}\text { - Selalu mencari } \\
\text { informasi tentang } \\
\text { produk tersebut } \\
\text { - Selalu informasi } \\
\text { tentang kebaikan } \\
\text { dari produk tersebut } \\
\text { dari orang lain }\end{array}$ \\
\hline
\end{tabular}

Sumber : Data Sekunder, diolah (2020)

\section{HASIL DAN PEMBAHASAN}

Analisis Deskriptif

Tabel 3. Garis Kontinum Variabel Media Sosial

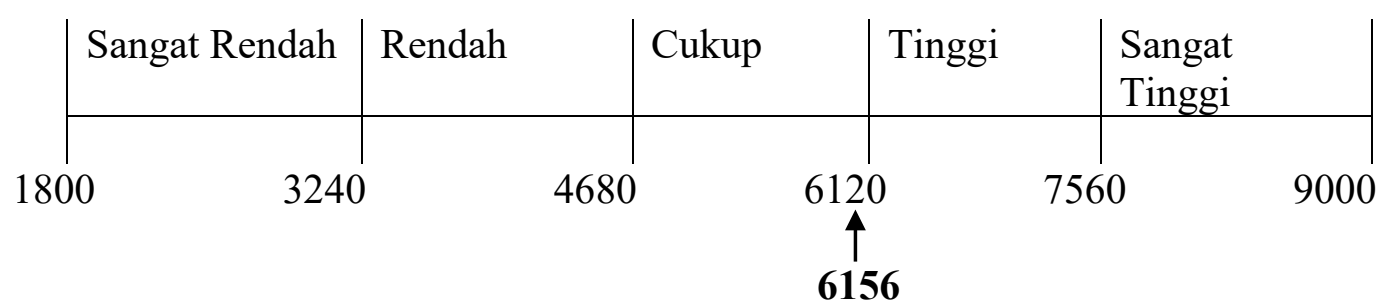

Berdasarkan tabel 3 diatas menunjukkan bahwa skor variabel media sosial adalah 6156 sedangkan skor ideal adalah 9000 maka variabel media sosial termasuk kategori tinggi dalam mempengaruhi minat kunjung terhadap wisata Ciwidey. 
Tabel 4. Garis Kontinum Variabel Atribut Produk

\begin{tabular}{|c|c|c|c|c|c|}
\hline & Sangat Rendah & Rendah & Cukup & Tinggi & $\begin{array}{l}\text { Sangat } \\
\text { Tinggi }\end{array}$ \\
\hline 1500 & 2700 & 3900 & 5100 & 6300 & 7500 \\
\hline
\end{tabular}

Berdasarkan tabel 4 diatas menunjukkan bahwa skor variable atribut produk adalah 5288 sedangkan skor ideal adalah 7500 maka variabel atribut produk masuk kategori tinggi dalam mempengaruhi minat kunjung terhadap wisata Ciwidey.

Tabel 5. Garis Kontinum Variabel Minat Kunjung

\begin{tabular}{|l|l|l|l|l|} 
Sangat Rendah & Rendah & Cukup & Tinggi & $\begin{array}{l}\text { Sangat } \\
\text { Tinggi }\end{array}$ \\
\hline 800 & & & & \\
\end{tabular}

Berdasarkan tabel 5 diatas menunjukkan bahwa skor variabel minat kunjung adalah 2902 sedangkan skor ideal adalah 4000 maka variabel minat kunjung masuk kategori tinggi.

\section{Analisis Regresi}

Tabel 6. Hasil Regresi Linier Berganda

\begin{tabular}{|c|c|c|c|c|c|c|}
\hline \multicolumn{7}{|c|}{ Coefficients $^{\mathrm{a}}$} \\
\hline \multirow[b]{2}{*}{ Model } & & \multicolumn{2}{|c|}{ Unstandardized Coefficients } & \multirow{2}{*}{$\begin{array}{c}\text { Standardized } \\
\text { Coefficients } \\
\text { Beta }\end{array}$} & \multirow[b]{2}{*}{$\mathrm{t}$} & \multirow[b]{2}{*}{ Sig. } \\
\hline & & $\mathrm{B}$ & Std. Error & & & \\
\hline \multirow[t]{3}{*}{1} & (Constant) & 15.474 & 2.245 & & 6.894 & .000 \\
\hline & Media Sosial & .091 & .053 & .223 & 1.731 & .087 \\
\hline & Atribut Produk & .186 & .070 & .341 & 2.655 & .009 \\
\hline
\end{tabular}

a. Dependent Variable: Minat Kunjung 
Berdasarkan pada tabel 6 diatas maka diperoleh persamaan regresi berganda yaitu :

$$
\mathrm{Y}=\mathbf{1 5 , 4 7 4}+\mathbf{0 . 0 9 1} \mathrm{X} 1+\mathbf{0 . 1 8 6} \mathrm{X2}
$$

Berdasarkan persamaan regresi tersebut bahwa terdapat pengaruh media sosial terhadap minat kunjung sebesar 0,091 atau 9,1\% dan pengaruh atribut produk terhadap minat kunjung sebesar 0,186 atau $18,6 \%$

\section{Uji F (Simultan)}

Uji F atau koefisien regresi secara bersama digunakan untuk mengetahui apakah media sosial dan atribut produk memiliki pengaruh yang signifikan atau sebaliknya terhadap minat kunjung.

Tabel 7. Hasil Uji Simultan

\begin{tabular}{|c|c|c|c|c|c|c|}
\hline \multicolumn{7}{|c|}{ ANOVA ${ }^{a}$} \\
\hline & & Sum of Squares & df & Mean Square & $\mathrm{F}$ & Sig. \\
\hline \multirow{3}{*}{$\frac{1}{1}$} & Regression & 479.789 & 2 & 239.895 & 18.763 & $.000^{\mathrm{b}}$ \\
\hline & Residual & 1240.171 & 97 & 12.785 & & \\
\hline & Total & 1719.960 & 99 & & & \\
\hline
\end{tabular}

a. Dependent Variable: Minat Kunjung

b. Predictors: (Constant), Sosial Media, Atribut produk

Berdasarkan pada Tabel 7 diatas, hasil uji F media sosial dan atribut produk terhadap minat kunjung adalah sebagai berikut :

1. Nilai F hitung adalah sebesar 18,763, kemudian dibandingkan dengan $F$ Tabel $(\mathrm{k}: \mathrm{n}$ - k). Diketahui bahwa jumlah responden $100(\mathrm{n}=100)$. Maka diperoleh F tabel ( 2 : $100-2)$ sebesar 2,04. Sehingga dapat diketahui bahwa nilai F hitung $(18,763 \geq$ 2,04). Maka H0 ditolak dan menerima H1, artinya secara simultan variabel social produk dan atribut produk berpengaruh positif terhadap minat kunjung.

2. Nilai signifikansi dalam uji $\mathrm{F}$ ini adalah 0,000 dan lebih kecil daripada taraf signifikansi 5\% $(0,000<0.05)$, maka H0 ditolak dan menerima H1. Artinya bahwa media sosial dan atribut produk secara bersama-sama berpengaruh signifikan terhadap minat kunjung wisata. 


\section{Uji t (Parsial)}

Pengujian hipotesis secara parsial untuk mengetahui apakah media sosial dan atribut produk memiliki pengaruh yang signifikan atau sebaliknya terhadap minat kunjung wisata Ciwidey.

\begin{tabular}{|c|c|c|c|c|c|c|}
\hline \multicolumn{7}{|c|}{$\begin{array}{c}\text { Tabel 8. Hasil Uji parsial } \\
\text { Coefficients }^{\mathbf{a}}\end{array}$} \\
\hline & & \multicolumn{2}{|c|}{ Unstandardized Coefficients } & \multirow{2}{*}{$\begin{array}{c}\text { Standardized } \\
\text { Coefficients } \\
\text { Beta }\end{array}$} & \multirow[b]{2}{*}{$\mathrm{t}$} & \multirow[b]{2}{*}{ Sig. } \\
\hline & & B & Std. Error & & & \\
\hline \multirow[t]{3}{*}{1} & (Constant) & 15.474 & 2.245 & & 6.894 & .000 \\
\hline & total_x1 & .091 & .053 & .223 & 1.731 & .087 \\
\hline & total $\times 2$ & .186 & .070 & .341 & 2.655 & .009 \\
\hline
\end{tabular}

a. Dependent Variable: $\mathrm{y}$

Hasil analisis uji parsial maka diperoleh hasil seberikut :

1. Pengaruh sosial media terhadap minat kunjung

Hasil uji empiris menunjukkan nila B sebesar 0.091 bahwa social media berpengaruh positif dan nilai signifikannya sebesar 0,087 berarti $>$ nilai alpha 0,05 maka pengaruh media sosial tidak signifikan terhadap minat kunjung wisata. Sehingga hasil penelitian menunjukkan media sosial berpengaruh positif dan tidak signifikan terhadap minat kunjung wisata.

2. Pengaruh atribut produk terhadap minat kunjung

Hasil uji empiris menunjukkan nila B sebesar 0.186, bahwa atribut produk berpengaruh positif dan nilai signifikannya sebesar 0,009 berarti $<$ nilai alpha 0,05 maka pengaruh atribut produk signifikan terhadap minat kunjung wisata. Sehingga hasil penelitian menunjukkan atribut produk berpengaruh positif dan signifikan terhadap minat kunjung wisata.

\section{Strategi Untuk Meningkatkan Minat Kunjung Kawasan Wisata Ciwidey}

1. Menjalin kerjasama dinas pariwisata setempat dan stakeholder untuk membuat dan mengelola akun sosial media instagram resmi sebagai pusat informasi wisata ciwidey.

2. Media sosial dapat memberikan informasi berbagai jenis wisata alam, budaya, agama, kuliner, MICE (Meeting, Incentives, Conference and Exhibition) dan 
kegiatan, wisata olahraga, dan pariwisata kawasan terpadu yang menarik berupa foto atau video.

3. Mengoptimalkan konten wisata ciwidey dan meningkatkan intensitas postingan foto/video objek wisata ciwidey

4. Menyediakan pilihan transportasi umum sebagai salah satu faktor penting dari produk wisata untuk mempermudah akses wisatawan yang berkunjung.

5. Melengkapi fasilitas pendukung pariwisata seperti ATM centre, tempat beribadah, toilet untuk kenyamanan.

\section{SIMPULAN}

1. Media Sosial berpengaruh positif tidak signifikan terhadap minat kunung wisata.

2. Atribut produk berpengaruh positif dan signifikan terhadap minat kunjung wisata.

3. Strategi untuk meningkatkan minat kunjung wisata di Ciwidey adalah menjalin kerjasama dinas pariwisata setempat dan stakeholder untuk membuat dan mengelola akun sosial media Instagram, sosial media dapat memberikan informasi berbagai jenis wisata alam, budaya, agama, kuliner, MICE (Meeting, Incentives, Conference and Exhibition) dan kegiatan, wisata olahraga, dan pariwisata kawasan terpadu yang menarik berupa foto atau video, mengoptimalkan konten wisata ciwidey dan meningkatkan intensitas postingan foto/video wisata ciwidey, menyediakan pilihan transportasi umum dan mempermudah akses wisatawan yang berkunjung dan melengkapi fasilitas pendukung pariwisata.

\section{DAFTAR PUSTAKA}

Akpoyomare, Ben, O., Adeosun, L. P., \& Ganiyu, R. A. (201). The Influence of Product Attributes on Consumer Purchase Decision in the Nigerian Food and Beverages Industry. American Journal od Business and Management, 196-201.

Amartin, L. (2018). Pengaruh Akun Instagram @EksploreBanten terhadap minat kunjung (Travelling) Wisata di Banten.

Hapsari, N. R., Lubis, N., \& Widiartanto. (2014). Pengaruh Atribut Produk Wisata dan Electronic Word of Mouth (e-WOM) Terhadap Keputusan Berkunjung pada 
Objek Wisata Umbul Sidomukti Kabupaten Semarang. Jurnal Ilmu Administrasi Bisnis.

Hasan, A. (2015). Marketing Tourism. Jakarta: Centre for Academic Publishing Service.

Kottler, P., \& Armstrong, G. (2012). Prinsip-Prinsip Pemasaran. Jakarta: Erlangga.

Muljadi, A. (2010). Kepariwisataan dan Perjalanan. Jakarta: Raja Grafindo Perkasa.

Nifita, \& Arishonda. (2017). Pengaruh Media Sosial Terhadap Minat Berkunjung Wisata di Taman Geopark Kabupaten Merangin .

Sanchez-Cañizares, S., \& Castillo-Canalejo, A. (2015). A Comparatived Study of Tourist Attitudes Towards Culinary Tourism in Spain and Slovenia. British Food Journal. Retrieved from https://doi.org/10.1108/BFEJ-012015-0008

Social, W. a. (2019). Most Active Social Media Platforms.

Sumardy, Silviana, M., \& Melone, M. (2011). The Power Word of Marketing. Jakarta: PT. Gramedia Pustaka Utama.

Sunarti, S. d. (2019). Pengaruh Media Sosial terhadap Minat Berkunjung FOLLOWERS (Survei pada Followers Akun Instagram @batuflowergarden.Cobanrais). Jurnal Administrasi Bisnis.

Suryani, I. (2017). Pemanfaatan Media Sosial Sebagai Media Pemasaran Produk Dan Potensi Indonesia Dalam Upaya Mendukung Asean Community 2015. Jurnal Komunikasi 8(2), 123-138. Retrieved from https://doi.org/10.20885/komunikasi.vol8.iss2.art2

Tjiptono, F. (2008). Strategi Pemasaran. Yogyakarta: BPFE.1. 